\section{GEOPHYSICAL INVESTIGATION OF GROUNDWATER POLLUTION RESULTING FROM LEACHATE FLOW AT IKOTO AND ORU DUMPSITES IN OGUN STATE OF NIGERIA}

${ }^{1}$ Talabi, Adetoro Temitope; ${ }^{1}$ Roy-Layinde, Taiwo Olakunle; ${ }^{2}$ Odunaike, Rasaki Kola; ${ }^{1}$ Oladunjoye, Hamid Titilope; ${ }^{1,3}$ Adebanjo, Aina Opeyemi

Department of Physics, Olabisi Onabanjo University, Ago-Iwoye, Nigeria.

${ }^{2}$ Department of Physics, University of Ibadan, Ibadan, Nigeria.

'Department of Geosciences, University of Lagos, Akoka, Nigeria.

Corresponding author: roy-layinde.taiwo@oouagoiwoye.edu.ng

\section{ABSTRACT}

An electrical resistivity survey was carried out to detect the level of groundwater pollution on Oru and Ikoto dumpsites respectively as it was observed that the dumpsites were sited ignoring the environmental and health hazard. The survey was conducted using ABEM model terrameter with schlumberger array for 1-D vertical electrical sounding (VES) of electrode spacing ranging from obtined from the field were interpreted using WINRESIST from which the curve types of The data area were identified. On Oru dumpsite, measurement of VES1 was taken on the dumpsite, VES2 was taken $20 \mathrm{~m}$ away from the dumpsite, VES3 and VES4 were taken across the road serving as control. Here, there is indication of leachate pollution in VES1 (layer 2) and VES2 (layer 3) while VES3 and VES4 are leachate free, but this leachate present in VES1 and VES2 cannot penetrate into the groundwater table because of the stratigraphy of the area. At Ikoto dumpsite, measurement of VES was taken on the dumpsite, VESI and VES2 were taken 30m away from the dumpsite on both sides, and while VES3 was taken across the Lagos/Ibadan expressway, serving as control. There is indication of leachate pollution in VES4 (laye2) while in VES1, VES2 and VES3 there is no presence of leachate flow. The leachate present in VES4 can infiltrate into the groundwater table through th

Accepted Date: 28 June 2018

\section{INTRODUCTION}

In many developing countries, waste management still poses significant health challenges basically because solid waste disposal method still remains as open dumping. Ignorance, poverty, population growth and high urbanization rates, poor living standards and lack of commitment from government to protect and improve public health and the environment has been identified as some of the major causes of the continuous practices of this risky waste disposal system (Cointreau 1982. Hussain et al. 1989; Doon, 1998; Wagh et al, 2014). The al. 1989; Doan, 1998; Wagh 2014). The probleng; Docm, lgg8; Wagh et al. as man itselfand is of majorconcento even nation of the world. Municipal solid waste management

constitutes one of the most disturbing health and environmental challenges facing most government especially in developing countries like Nigeria and it is an enormous task (Agumwamba et al., 2003). This is partly due to the fact that the rate of generation of solid waste in our society is increasing with meteoric rise in population (Allende, 2009; Ochuko, 2015). Many old landfills existing throughout Nigeria pose a threat to human and environmental well-being.

Waste is any material lacking direct value to the user and so must be disposed while dumpsite is as a place where accumulations of refuse or other discarded materials are dumped (Babatola, 2008). Solid wastes are generally classified into two broad categories base on direct health implication; (i) Hazardous wastes: toxic chemicals like herbicides, insecticides, industrial run-off; radioactive materials; flammable and explosive wastes including propane and bi-products of crude oil and (ii) Non-hazardous wastes from agriculture, commercial and industrial wastes that do not contain radioactive or toxic materials (Fasunwon et al., 201). Unfortunately, most of these dumpsites were sited ignorantly in places that pose environmental and health hazards. Wastes placed in landfills are subject to either percolation of fluvial water or infiltration of contaminants from organic and inorganic compounds usually disposed as industrial waste, ash, waste treatment sludge, household hazardous wastes, or from normal waste decomposition through the soil. The polluted water which then accumulate at the base of the dumpsite is termed 'leachate' and may permeate through the soil depending on the stratigraphy of the site (Mor et al., 2006). More so, the dumped waste is expected to naturally biodegrade and generates leachate or effluent (Osazuwa and Abdullah, 2008). If left uncontrolled, landfill leachate can be responsible for polluting ground and surface waters (Slomczynska and Slomczynski, 2004; Lawal et al., 2013). The impact of dumpsites has been a challenge and threat to groundwater. When water percolates through the waste, picking up pollutants such as heavy metals, organic chemicals, microorganisms, flammables and radioactive materials and flows into the groundwater table, it pollutes the groundwater.

Groundwater is among the world's most abundant natural resources and it worch for abound 40 percent of water used for the public and main sources of drinking water. It is the fortress of most springs and supplies much of the water in ponds, streams, rivers, and bays. The importance of protecting and maintaining the quality and quantity of this water resource cannot be over emphasized as it is a major building block of all lives. The state surface water scheme in Ogun State has not been able to fully meet the water needs of the populace which has necessitated recourse to waste water, industrial discharges, agricultural waste, urban runoff, landfills or waste dump and groundwater (Adebayo et al.,2015). Over the years, there have been many proposals on improving environmental sanitation especially through construction of suitable refuse dumpsite (Ikhifa and Umego, 2016) but most of the appalling situation still persists. Therefore, for any effort on the control of leachate migration and its resultant effect of polluting the groundwater to be realistic, there is need to subject these landfills to stringent survey, design, construction and maintenance routines as contaminated groundwater is very costly to clean up. The survey of the level of groundwater pollutant (leachate) is necessary as it helps to control diseases and makes water safe for daily use. Geophysical survey is essential tools widely used in detecting, mapping, and studying the characteristics of various subsurface materials and structures. Leachate generally has high ion content, hence very low resistivity of the rock formations containing them. This makes geophysical techniques most applicable for mapping the amount of leachate contamination around dumpsites. In particular, geo-electrical techniques are employed in geo-scientific investigations because of their ability to effectively map broad spectrum of composite images of the subsurface at relatively lower cost and higher speed to reved information on the depth to bedrock, the extent of sanitation and porosity of the underlying materials (Badmus et al., 2014; Ganiyu et al., 2015). Electrical resistivity method is a wellestablished and more diversified approach to solving a variety of geotechnical, hydrogeological and environmental issues than other geophysical methods due to the simplicity and efficiency of its technique. In this research, the electrical resistivity method was adopted to carry out geophysical survey of leachate migration at Oru Ijebu and Ikoto dumpsites which are located in communities presently facing challenges of clean underground water with the scope of understanding the porosity and permeability of the subsurface stratigraphy.

\section{THE STUDYAREAS}

The study areas are located in Ogun state, Nigeria. Fig. 1 shows the map of Ogun state with the study areas (Oru-Ijebu and Ikoto) marked out for identification within their local government areas. (Fig. 1)

Oru-Ijebu lies within the basement complex of Southwestern Nigeria and located between 
longitude $3^{\circ} 50^{\prime}$ to $3^{\circ} 57^{\prime} \mathrm{E}$ and latitude $6^{\circ} 55^{\prime}$ to $6^{\circ} 70^{\prime} \mathrm{N}$ in Ijebu North local government, Ogun State. The area is leading to the dumpsite (SITE 1) from the main road in the area as shown in Fig. 2. Oru is a representative of both the migmatite gneiss complex and the older granite, which shows structural disposition. Oru-Ijebu is characterized by a tropical climate with alternating wet and dry seasons, its relief is moderately high and it has a gradient of approximately 1/600 giving a nearly flat topography (Ariyo and Enikanoselu, 2007).

Ikoto is as well a part of the South Western Nigeria. It is within a sedimentary area and lies between latitude $6^{\circ} 49^{\prime} 15^{\prime} \mathrm{N}$ and longitude $3^{\circ} 55^{\prime} 15^{\prime}$ in Odogbolu local government, Ogun state. The dumpsite is located along a major road, SagamuBenin highway which links the eastern and western parts of the country and it is $110 \mathrm{~km}$ by road north of Lagos. It can also be accessed through a web of major and minor roads from neighboring communities as shown in Fig. 3. It has a typical rainforest vegetation and moderately hot, hical

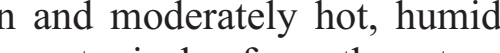
tropical climate zone typical of southwestern Nigeria. Ikoto dumpsite (SITE 2) is located at Faari, Ikoto which is situated along the A121 highway, few kilometers away from Tai Solarin University of Education (TASUED). The characteristics of the dumpsites are highlighted in Table 1.

\section{MATERIALS AND METHODS}

The electrical resistivity method was adopted for the survey because of its high response to water bearing materials as it indicates the conductivity nature of underground layer(s). In all electrical resistivity surveying techniques, a known electrical current is passed through the ground through the current electrodes. The potential of the electrical field resulting from the application of the current is measured via the potential electrodes at various locations. Since the current is known and the potential can be measured, an apparent resistivity potential can be
can be calculated.

The Vertical Electrical Sounding (VES) data were acquired using ABEM Terrameter model. Four (4) VES data were acquired in each study area using the Schlumberger electrode configuration. The Terrameter was powered using a $12 \mathrm{~V}$ battery to generate a powerfils Terrameter for the measurement. Other equipment used for the survey include; four metal steel rod used as electrodes, measuring tapes, hammers, reels of copper wire and Global Positioning Syster (GPS). The electrodes were arranged using the Schlumberger configuration array and were planted firmly to the ground to avoid leakage current for the good sounding procedure. The cables were connected to the electrodes using a clip gadget to the Terrameter. The first reading was gaken to the Teredo the electrodes using a dip taken by placing the potential electrodes an current electrodes at $0.25 \mathrm{~m}$ and $1 \mathrm{~m}$ respectively from the mid-point (sounding point). The curren electrodes were then shifted symmetrically with respect to the mid-point up the distance of $100 \mathrm{~m}$. This is because the sounding depths depend solely on the distance between the current electrodes $(\mathrm{AB} / 2)$. The potential electrodes were only shifted at specified cases so that the Terrameter could measure the corresponding resistivity arising from the current injected into the subsurface.

Measurement of VES1 was taken on the dumpsite, VES2 was taken $20 \mathrm{~m}$ away from the dumpsite, VES3 and VES4 were taken across the road opposite the dumpsite about $15 \mathrm{~m}$ away from the road and $40 \mathrm{~m}$ from the dumpsite in Oru-Ijebu. Measurement of VES1 and VES2 were taken 30m away from the dumpsite on both sides, VES4 was taken on the dumpsite, and while VES3 was taken across the Lagos/Ibadan expressway opposite the dumpsite about $15 \mathrm{~m}$ away from the road and $30 \mathrm{~m}$ from the dumpsite in Ikoto, in other to estimate the distance covered by the pollutant.

\section{DATA PROCESSING}

Resistivity values obtained were first manually plotted against their respective current-electrode spacing values $(\mathrm{AB} / 2)$ on a $\log$-log graph, partially curve-matched and then electronically iterated using computer program (to obtain the geo-electric layers which show vertical variation in resistivity values with depth). This software showed the values with depth), This sofware showed the number of layers in each VES point with their respective resistivity value and their corresponding thickness. The interpretation of the sounding curves was done both quantitatively an qualitatively. The qualitative interpretation entails the observation of the sounding curves from the manual plots on the bilogarithm paper. The quantitative quantitative interpretation involves the use of partial curve matching.

\section{RESULTS AND DISCUSSION}

\section{A. Oru dumpsite}

The resistivity values obtained from Oru dumpsite ranges from $17.012 \Omega \mathrm{m}$ to $895.8 \Omega \mathrm{m}$. VES1 has the highest resistivity values followed by VES4, VES3 and then VES2.

The qualitative and quantitative analyses of the VES curves from Oru dumpsite are presented in Table 2. The VES plots obtained from computer iteration of the resistivity values are presented in Fig. 4 (a-d). Table 3 presents the curve types and layers within the site. Fig. 5 was generated to picture the frequency of curve types within the site using a bar chart. Three (3) curve types were obtained. Furthermore, the results of the investigation revealed the presence of three (3) to four (4) layers, with depth ranging from $0.5 \mathrm{~m}$ to $11.7 \mathrm{~m}$.

The area composed of topsoil, clay, sand, and weathered layer, fresh basement with three and four layers as shown in the geo-electric section presented in Fig.6.

The VES1 with three (3) layers has topsoil, leachate contamination, dry sand and weathered layer, formation with resistivity values of $138.8 \Omega \mathrm{m}$, $55.1 \Omega \mathrm{m}, 2655.0 \Omega \mathrm{m}$. It has thicknesses of $1.5 \mathrm{~m}$, $3.7 \mathrm{~m}$, and with depth $1.5 \mathrm{~m}, 5.2 \mathrm{~m}$, and infinity respectively. The low resistivity values indicate the presence of the leachate pollution in VES 1 (layer 2) which but can not directly infiltrate into the groundwater through the less porous and impermeable (Aquiferous) dry sand in subsurface layer.

The VES2 with depth has topsoil, clay, leachate contamination, weathered layer and formation having respective resistivity values of $11.1 \Omega \mathrm{m}$, $61.7 \Omega \mathrm{m}, 11.3 \Omega \mathrm{m}$ and $639.9 \Omega \mathrm{m}$; thicknesses of $0.5 \mathrm{~m}, 2.1 \mathrm{~m}, 5.6 \mathrm{~m}$ and infinite; with depths of $0.5 \mathrm{~m}$, $2.6 \mathrm{~m}, 8.1 \mathrm{~m}$ and infinite. Also the low resistivity 2.6m, $8.1 \mathrm{~m}$ and infinite. Also the low resistivity values implies the presence of leachate pollution in
VES 2 (layer 3) but cannot directly infiltrate into the groundwater through the less porous and impermeable (Aquiferous) dry sand in subsurface layer. (As in VES1 above) this also cannot cause contamination of the ground water because of its strong overburden layer.

In VES3, with depth, indicates that the profile has top soil, clay, and weathered layer formation with resistivity values of $34.6 \Omega \mathrm{m}, 94.9 \Omega \mathrm{m}, 1784.4 \Omega \mathrm{m}$ respectively. The thicknesses of the layers being $4.1 \mathrm{~m}, 2.0 \mathrm{~m}$ and depths of $4.1 \mathrm{~m}, 6.1 \mathrm{~m}$ respectively. This result reveals high resistivity values compared to VES 1 and VES 2 implying absence of pollution. This area cannot be polluted due to its stratigraphy. VES4 with depth shows that it has top soil, clay, frS4 with deth shows that it has top soil, clay fresh basenent fors resistivity values of $69.4 \Omega \mathrm{m}, 88.5 \Omega \mathrm{m}, 5417.6 \Omega \mathrm{m}$ respectively, and infinite thicknesses and depths. This reveals high resistivity values compared to VES 1 and VES 2, also implying that pollution is absent. This area may not be polluted due to its stratigraphy, as shown in the geo-electric section.

\section{B. Ikoto dumpsite}

The resistivity values obtained ranges from $72.819 \Omega \mathrm{m}$ to $3062.7 \Omega \mathrm{m}$, with VES3 having the highest resistivity values followed by VES4, VES1 and then VES2. The qualitative and quantitative analysis of the VES curves is presented in Table 4. The VES plots obtained from computer iteration of the resistivity values are presented in Fig.7 (a-d) Two (2) curve types were obtained as presented in Table 5. Fig 8 shows the frequency of curve types Table 5 . the result of the investigation reveals the presence of three (3) layers, with depth ranging from $0.6 \mathrm{~m}$ to $56 \mathrm{~m}$.

Fig. 9 is a geo-electric section generated to connect all the VES points within the study area - Ikoto dumpsite. The geo-electric section shows the variations of resistivity and thickness of layers. The area composed of topsoil, sand, Sandstone, weathered layer, fractured layer with three layers. The VES1 with depth has topsoil, weathered layer, and fresh basement formation with resistivity values of $398.3 \Omega \mathrm{m}, 1235.9 \Omega \mathrm{m}$, and $6872.4 \Omega \mathrm{m}$. It has thicknesses of $1.3 \mathrm{~m}, 54.7 \mathrm{~m}$ and infinite with depth $1.3 \mathrm{~m}, 56.0 \mathrm{~m}$ and infinite respectively. The resistivity value is regular compared to VES4, this implies absence of pollution but may be present 
with time due to the stratigraphy of the study area. The VES2 has top soil, sand and sandstone formation with depths of $70.7 \Omega \mathrm{m}, 92.6 \Omega \mathrm{m}$, and $654.4 \Omega \mathrm{m}$, resistivity values of $70.7 \Omega \mathrm{m}, 92.6 \Omega \mathrm{m}$, and $654.4 \Omega \mathrm{m}$, respectively; thicknesses of $0.6 \mathrm{~m}$, and $654.4 \Omega \mathrm{m}$, respectively; thicknesses of $0.6 \mathrm{~m}$,
$9.4 \mathrm{~m}$ and infinite with depths of $0.6 \mathrm{~m}, 10 \mathrm{~m}$ and infinite, respectively. The resistivity values are regular compared to VES4, this reveals that pollution is absent but may be present with time due to the stratigraphy of the study area. The VES3 with depth has top soil, weathered layer and fresh basement formation having respective resistivity values of $655.2 \Omega \mathrm{m}, 1754.9 \Omega \mathrm{m}$ and $3075.3 \Omega \mathrm{m}$; . of $0.7 \mathrm{~m}, 9.2 \mathrm{~m}$ and implies that pollution may not be present due to the

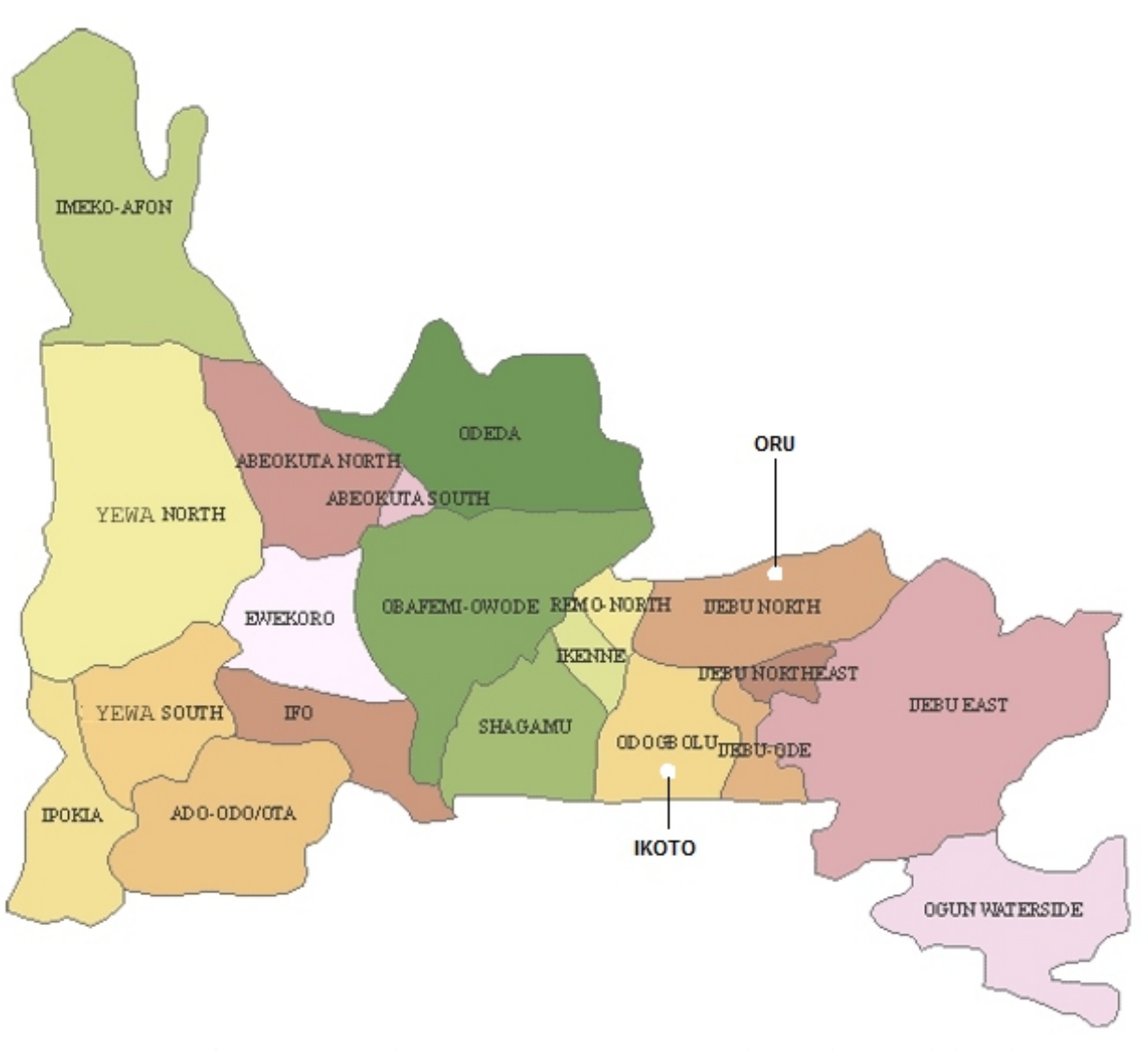

Fig.1: Map of Ogun State showing Oru community within Ijebu North local Government and Ikoto situated in Odogbolu Local Government stratigraphy of the study area. The VES4 with depth has topsoil, sand (Leachate contamination), fractured layer formation with resistivity values of $2650.3 \Omega \mathrm{m}, 298.6 \Omega \mathrm{m}, 3603.2 \Omega \mathrm{m}$. It has thicknesses of $1.0 \mathrm{~m}, 4.5 \mathrm{~m}$ and infinity with depth $1.0 \mathrm{~m}, 5.5 \mathrm{~m}$, and infinity respectively. The low resistivity values reveals the presence of the leachate pollution in VES 4 (layer 2) which can directly infiltrate into the groundwater through the highly porous and permeable (Aquiferous) sandstone into a fractured layer in subsurface layer, as indicated in the geo-electric section below in

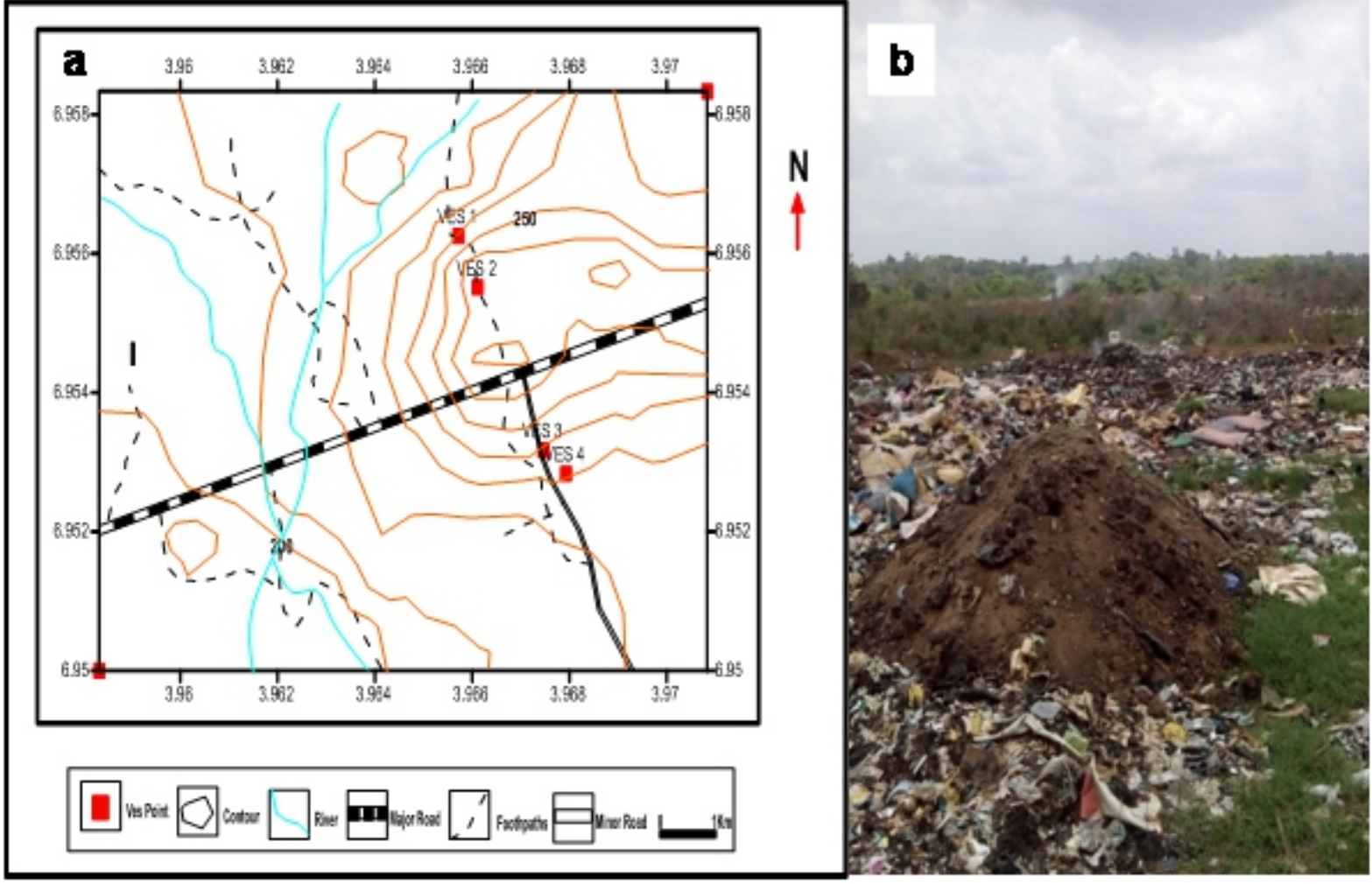

Fig. 2: The Base map of the VES points for Oru dumpsite (a) and Pictorial view of part of the dumpsite (b).
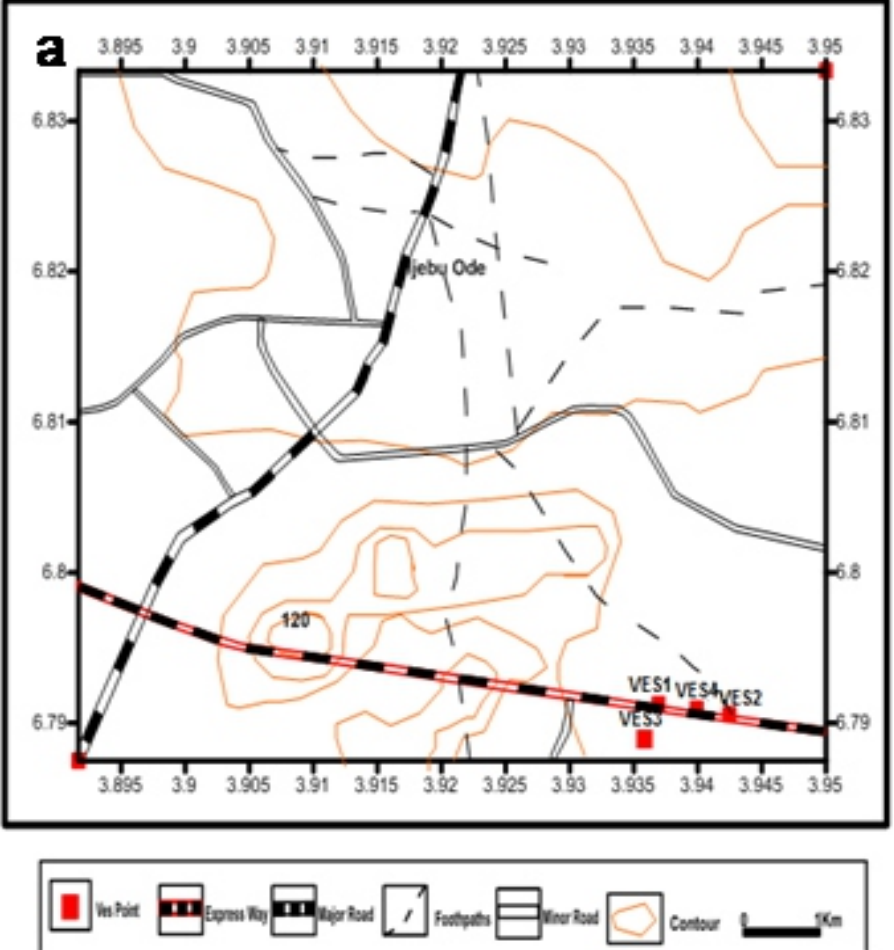

Fig. 3: Same as Fig. 2 but for Ikoto dumpsite.

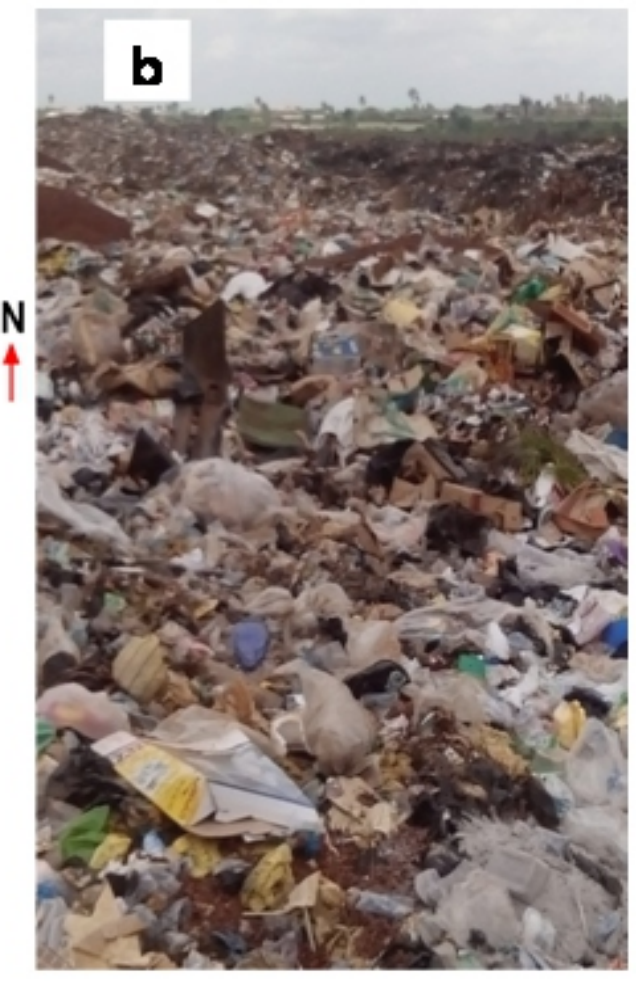


Table 1: Characteristics of landfill at Oru (SITE 1) and Ikoto (SITE 2) from information obtained from local ommunity members during reconnaissance survey of study areas.

\begin{tabular}{lll}
\hline Dumpsite characteristics & Site 1 & Site 2 \\
\hline Age and size of Landfill & $\begin{array}{l}\text { 10-12 years; 6 hectares and } \\
\text { elevation of about 6 meters } \\
\text { above ground level } \\
\text { Open dump system, Non- } \\
\text { hazardous waste. }\end{array}$ & $\begin{array}{l}\text { 15years; 6 hectares and } \\
\text { elevation of about 6 meters } \\
\text { above ground level }\end{array}$ \\
$\begin{array}{l}\text { Non-hazardous waste and it is } \\
\text { an Open dump system. }\end{array}$ \\
$\begin{array}{ll}\text { Degree of decomposition } \\
\text { Physical modification of waste }\end{array}$ & $\begin{array}{l}\text { None (No shredding of waste } \\
\text { or any form of recycling } \\
\text { activities) }\end{array}$ & $\begin{array}{l}\text { High (Natural decomposition) } \\
\text { None (No shredding of waste } \\
\text { or any form of recycling } \\
\text { activities) }\end{array}$
\end{tabular}
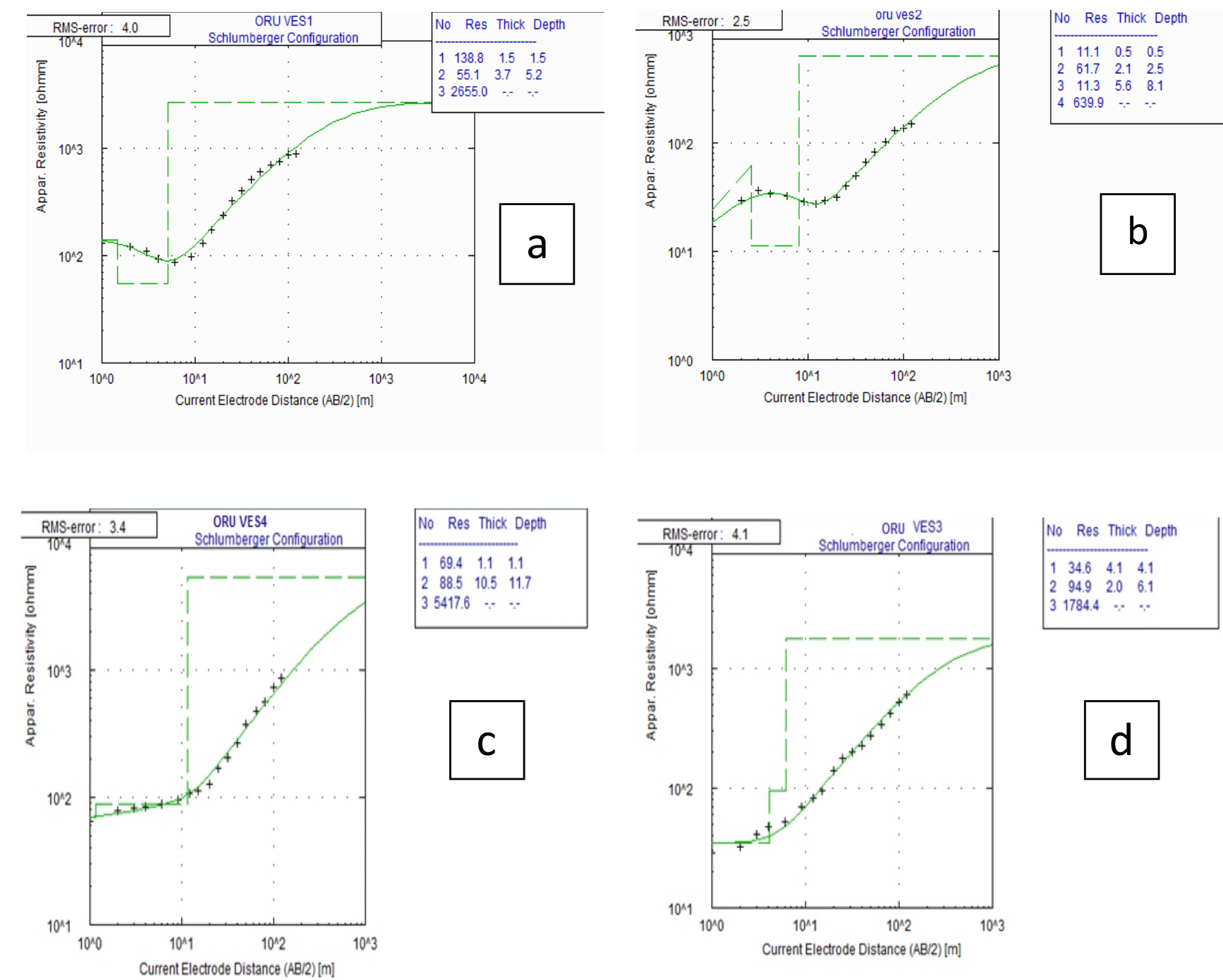

Fig.4: VES Curves for Oru dumpsite with VES1, VES2, VES3 and VES4 curves labeled as a, b. $c$ and d respectively.
Table 2: Qualitative and Quantitative of VES curve obtained from Oru dumpsite

Number of Resistivity Thickness Depth Curve

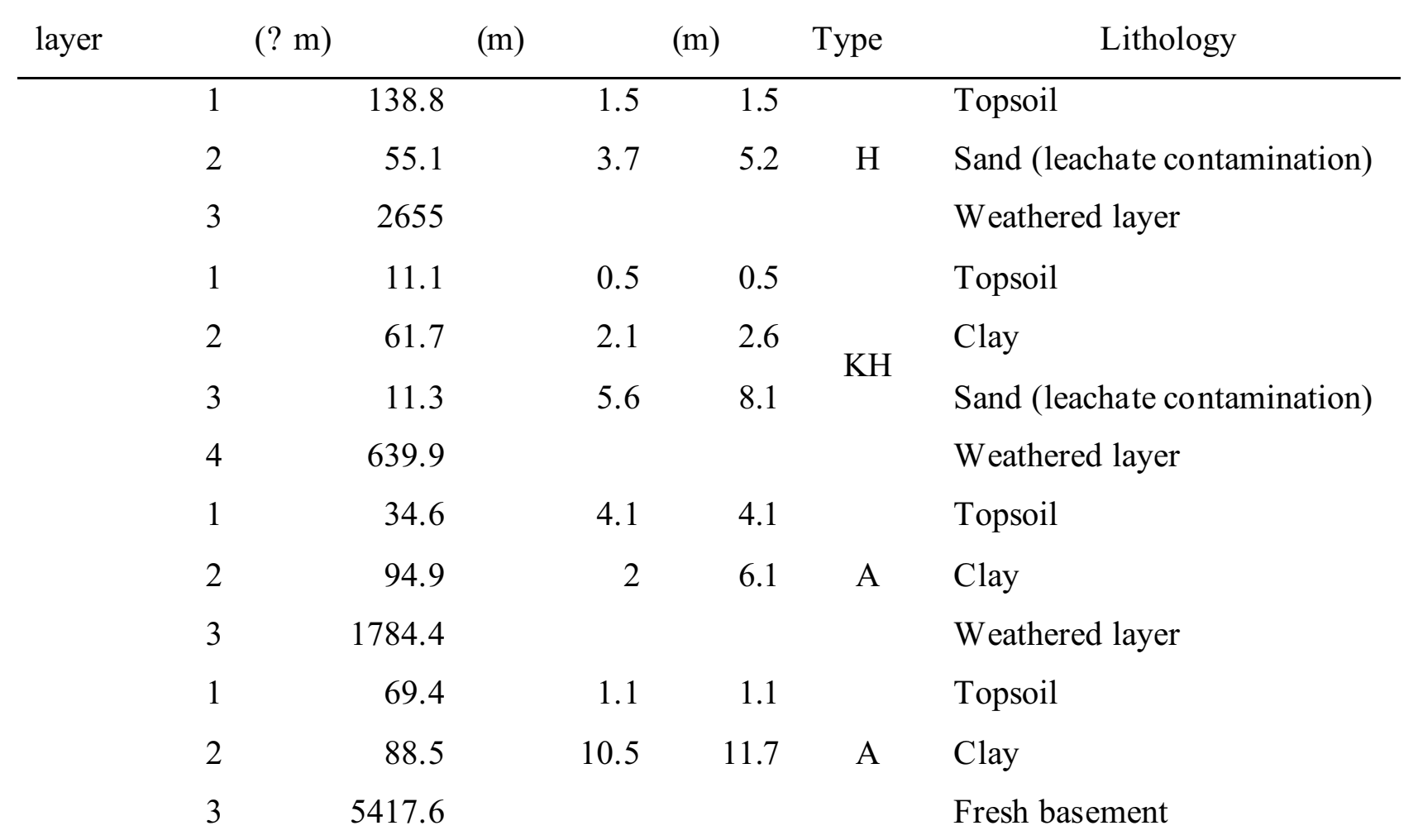

Table 3: curve types within Oru dumpsite

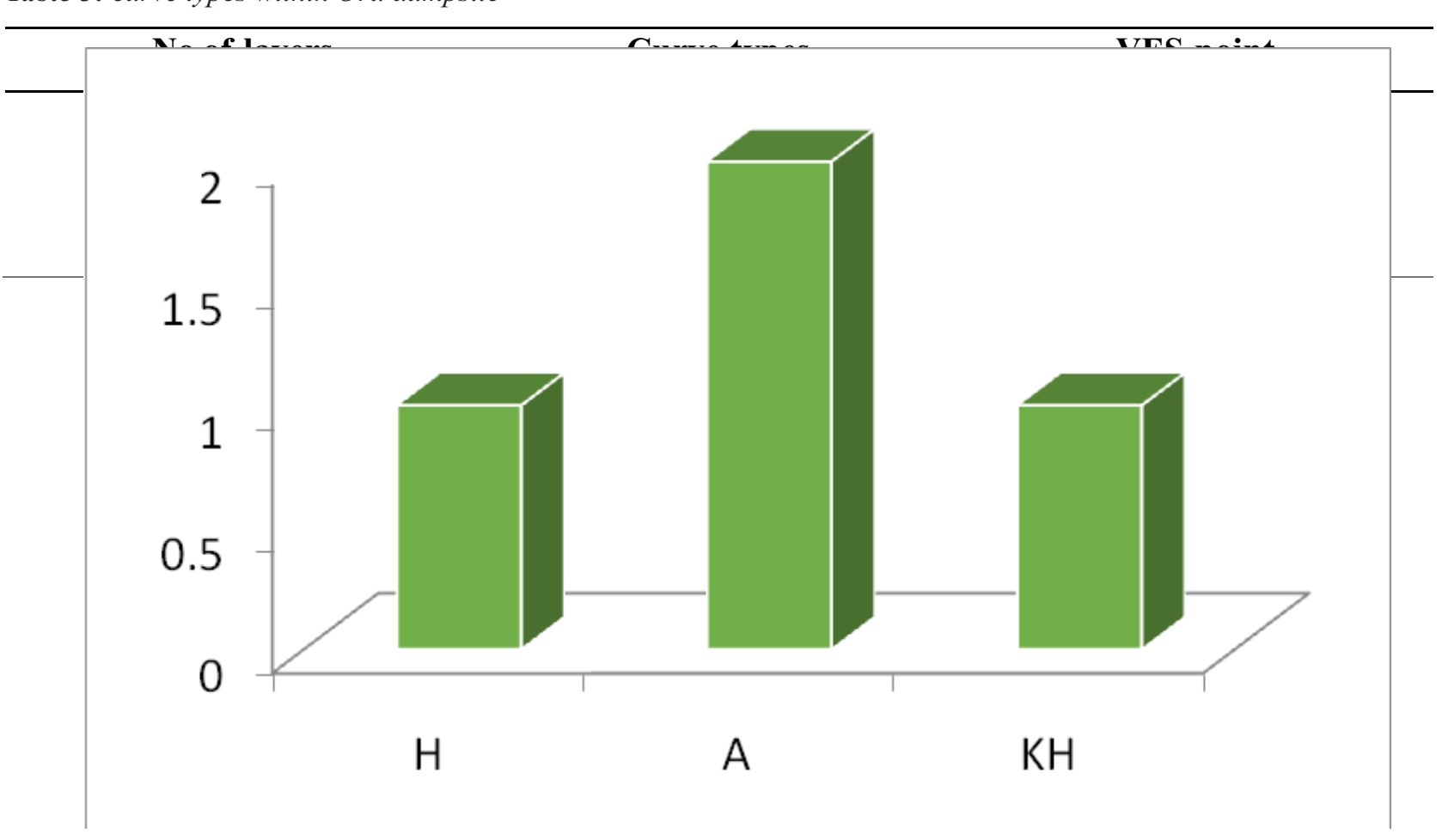

Fig. 5: Frequency of curve types within the Oru dumpsite 


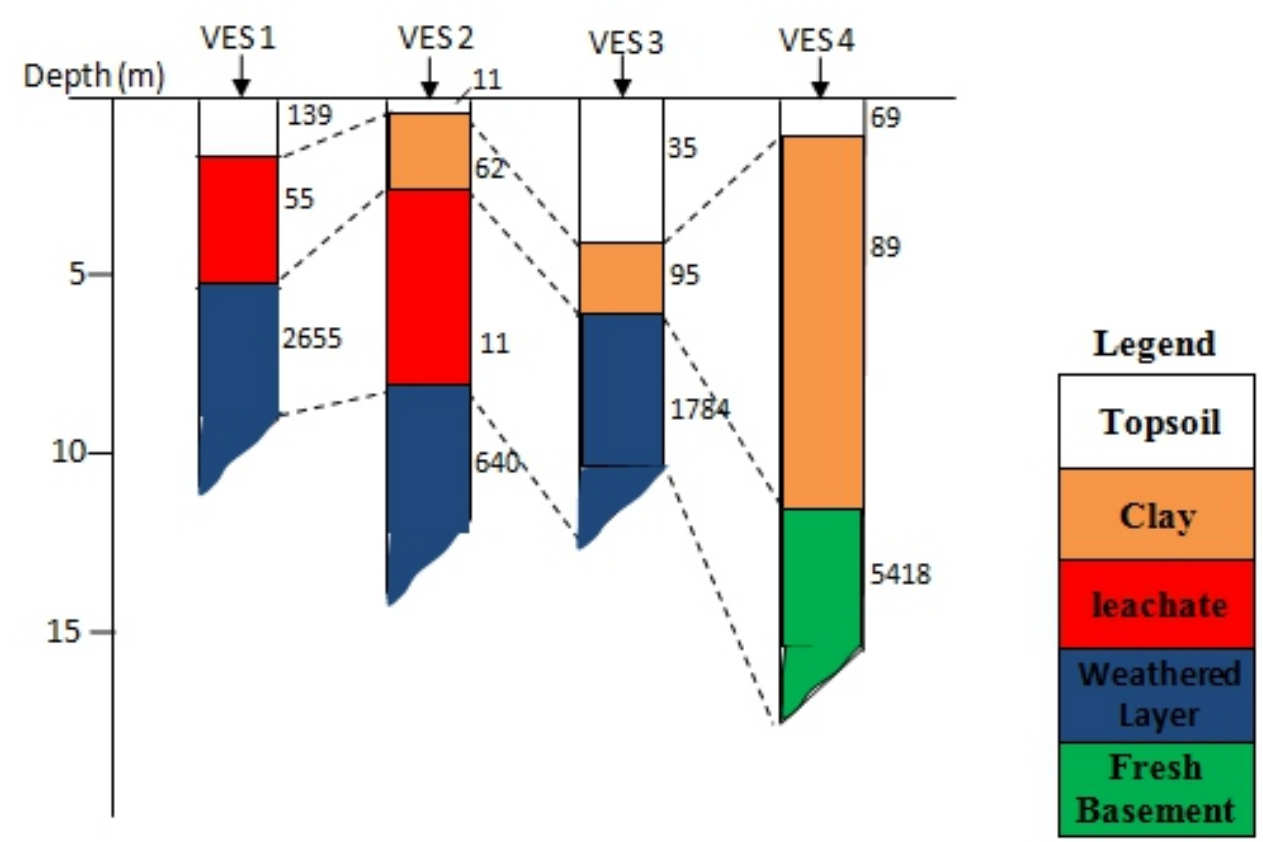

Fig.6: Geo-electric section of Oru dumpsite VES
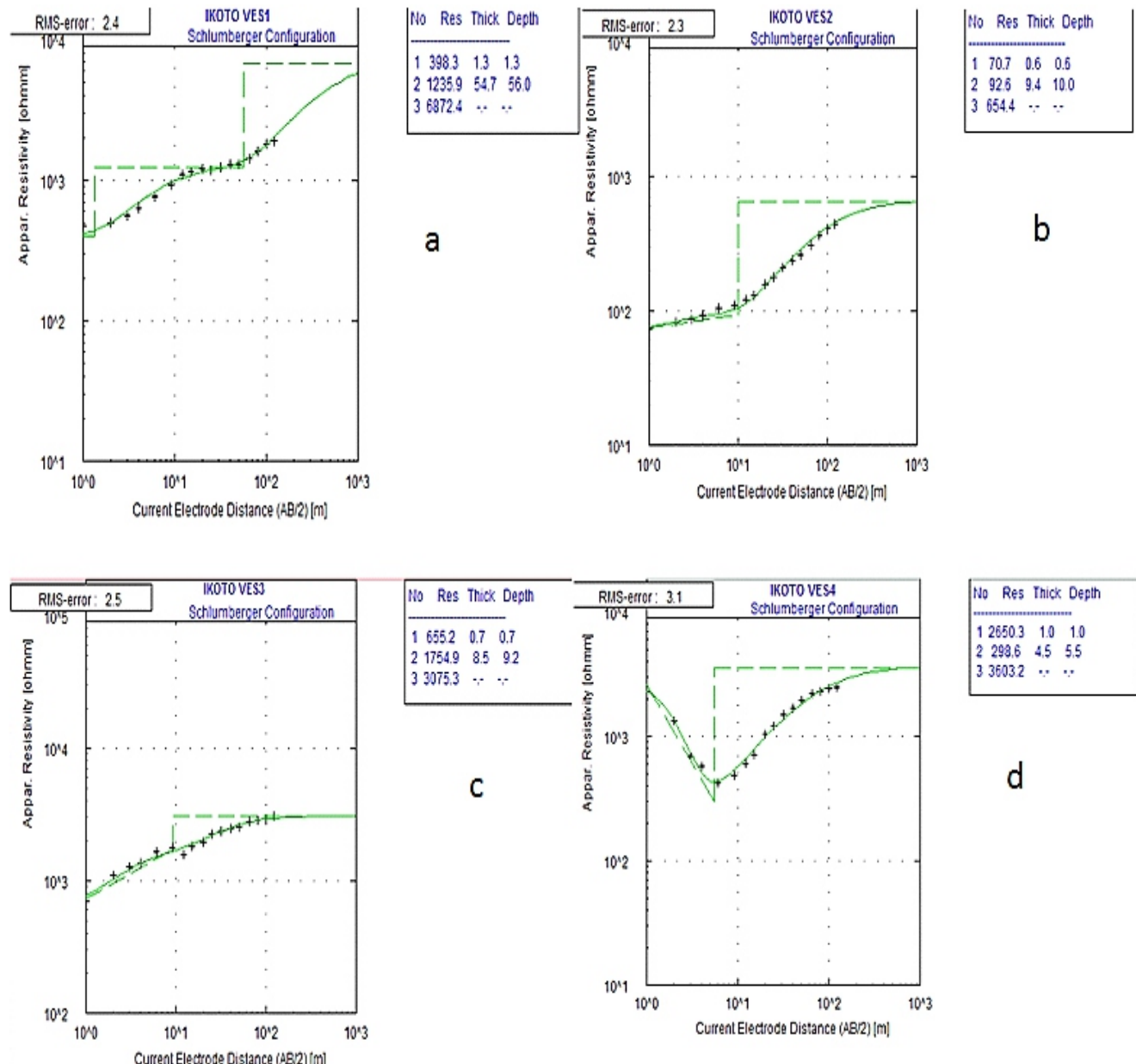

Fig.7: VES Curves for Ikoto dumpsite with VES1, VES2, VES3 and VES4 curves labeled as a, $b, c$ and $d$ respectively.

AsN

P-ISSN 2536-6904 African Journal of Science \& Nature Vol6, 1-13 (2018)
Table 4: Qualitative and Quantitative of VES curve obtained from Ikoto Dumpsite

\begin{tabular}{|c|c|c|c|c|c|c|c|}
\hline $\begin{array}{l}\text { VES } \\
\text { NO }\end{array}$ & $\begin{array}{l}\text { Number } \\
\text { of layer }\end{array}$ & & $\begin{array}{l}\text { Resistivity } \\
(? \mathrm{~m})\end{array}$ & $\begin{array}{l}\text { Thickness } \\
\text { (m) }\end{array}$ & $\begin{array}{l}\text { Depth } \\
\text { (m) }\end{array}$ & $\begin{array}{l}\text { Curve } \\
\text { Type }\end{array}$ & Lithology \\
\hline \multirow[t]{3}{*}{1} & & 1 & 398.3 & 1.3 & 1.3 & & Topsoil \\
\hline & & 2 & 1235.9 & 54.7 & 56 & A & Weathered layer \\
\hline & & 3 & 6872.4 & & & & Fresh basement \\
\hline \multirow[t]{3}{*}{2} & & 1 & 70.7 & 0.6 & 0.6 & & Topsoil \\
\hline & & 2 & 92.6 & 9.4 & 10 & A & Sand \\
\hline & & 3 & 654.4 & & & & Sandstone \\
\hline \multirow[t]{3}{*}{3} & & 1 & 655.2 & 0.7 & 0.7 & & Topsoil \\
\hline & & 2 & 1754.9 & 8.5 & 9.2 & A & Weathered layer \\
\hline & & 3 & 3075.3 & & & & Fresh basement \\
\hline \multirow[t]{3}{*}{4} & & 1 & 2650.3 & 1 & 1 & & Topsoil \\
\hline & & 2 & 298.6 & 4.5 & 5.5 & $\mathrm{H}$ & sand (Leachate contanimation) \\
\hline & & 3 & 3603.2 & 3.1 & 4.6 & & Fractured layer \\
\hline
\end{tabular}

Table 5: curve types within Ikoto dumpsite

\begin{tabular}{lll}
\hline No of layers & Curve Types & VES Points \\
\hline 3 & A & 1,2 and 3 \\
3 & H & 4 \\
\hline
\end{tabular}

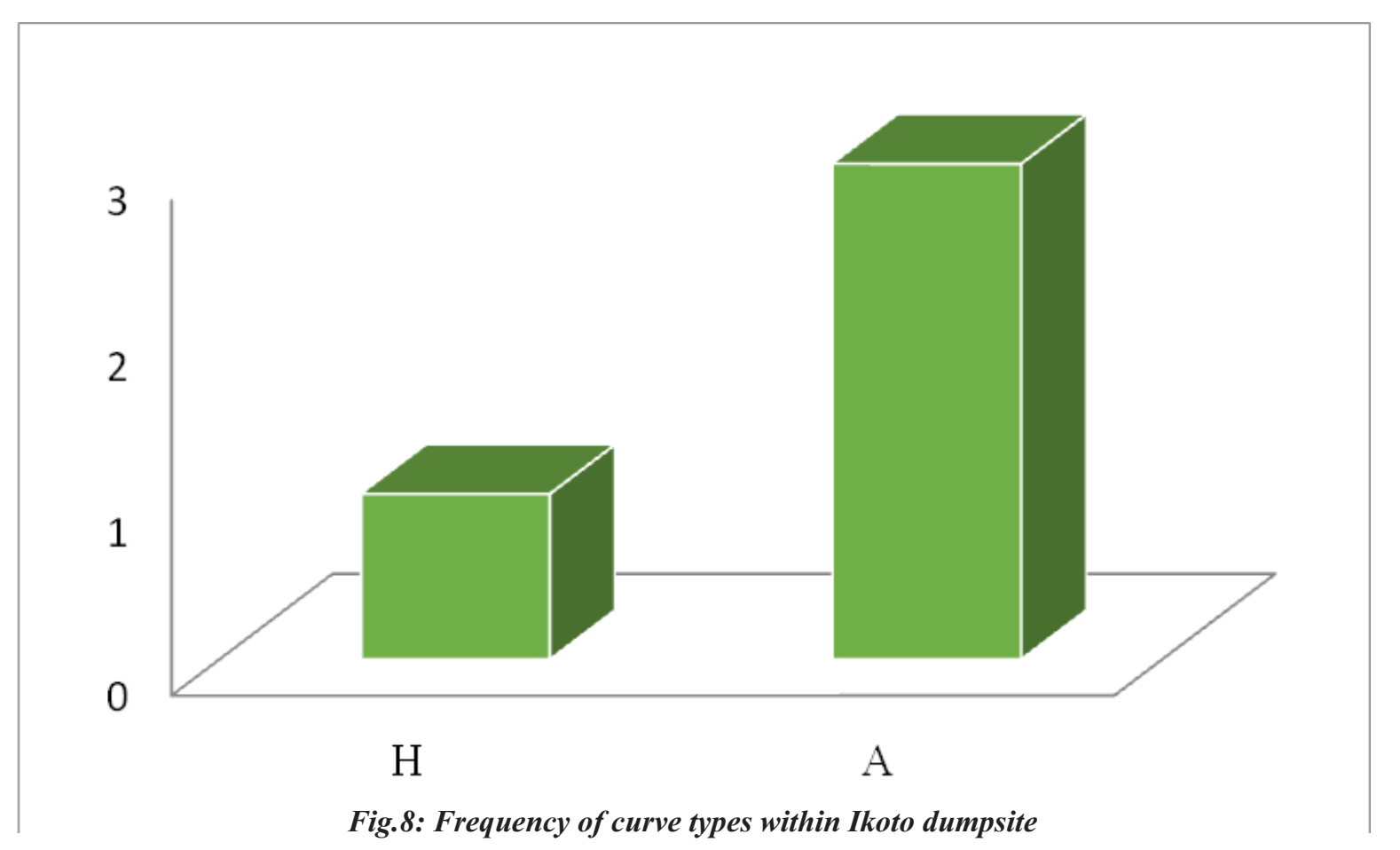

P-ISSN 2536-6904 African Journal of Science \& Nature Vol.6, 1-13 (2018) 


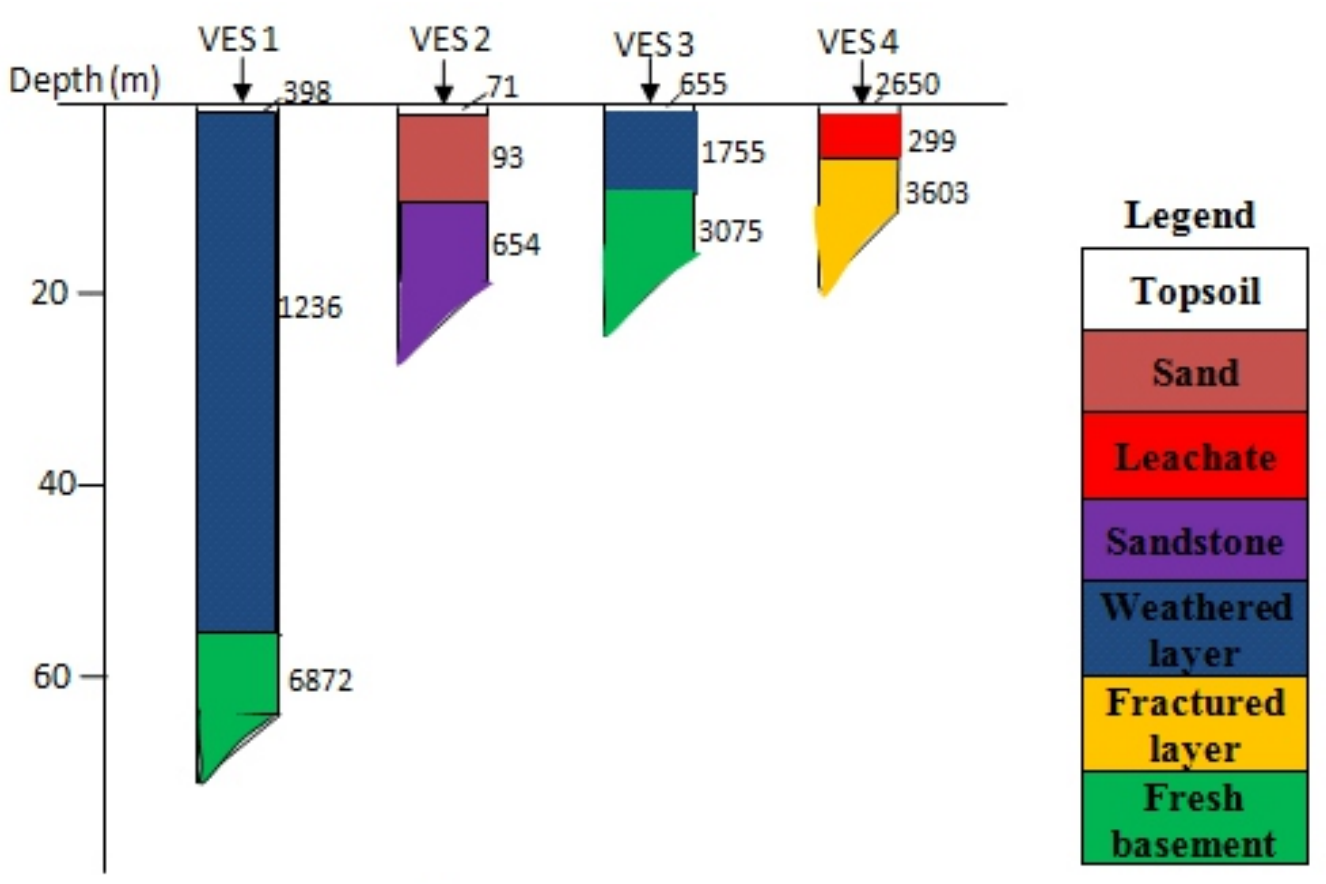

Fig.9: Geo-electric section of Ikoto dumpsite VES

\section{CONCLUSION}

Electrical Resistivity Method using Vertical Electrical Sounding (VES) has been employed to successfully delineate subsurface stratigraphy as preliminary investigations to underground water contamination through leachate migration in Oru and Ikoto, Ogun State, southwestern Nigeria.

Oru dumpsite consist of topsoil, sand, dry sand, clay, weathered layer, and fresh basement, indicating that the dumpsite is located on weathered layer. Other locations around the dumpsite are located on fresh basement. Low resistivity values of VES1 and VES2 revealed the presence of subsurface leachate pollution on the dumpsite, while the high resistivity values of VES3 and VES4 compared to VES1 and VES2 implied absence of pollutants as these areas are less porous and impermeable due to their stratigraphy (strong overburden layer). This survey revealed the dumpsite in Ikoto consist topsoil, sand, Sandstone, weathered layer, fractured layer, indicating that the dumpsite is located on fractured layer. The low resistivity values in VES4 reveal the presence of the leachate pollution (Barker 1990; Lawal et al. 2013) on the lumpsitewhich can directly pentr. 2013) into the subsurface water due to high porosity an permeability of the under lying layers (Aquiferous) sandstone into a fractured layer to the fres basement in subsurface layer. On the other hand, other locations around the dumpsite are located on weathered layer and sandstone. The resistivity values of VES1, VES2 and VES3 is regularly increased compare to VES4, this implies absence of pollution but may be present with time due to the with time due to the

With the findings of the authors of this research work, the next stage of this research starts with collection of leachate samples from the site to really ascertain the composition of these leachates. Physical, chemical and microbiological assessment will be done to test for the quality of the groundwater in correspondence to the WHO standard.

\section{REFERENCES}

Adebayo, A.S., E.A. Ariyibi, M.O. Awoyemi, and G.C. Onyedim (2015), Delineation of

Contamination Plumes at Olubonku Dumpsite Using Geophysical and Geochemical Approach at Ede Town, Southwestern Nigeria, Geosciences, 5(1), South

Agunwamba, J.C., N. Egbuniwe, and T.C. Ogwueleka (2003), Least cost management of Solid waste collection, Journal of Solid Waste Technology and Management, 29(3), 154-167

Allende, R. (2009), Waste history in the Gambia, M.Sc. Thesis. University of the Gambia

Ariyo, S. O., and E. M. Enikanoselu, (2007). Integrated use of Geoelectrical Imaging and Geochemical analysis in the environmental impact assessment of Egbe dumpsite In Ijebu-Igbo Area / South Western Nigeria. Continental Journal of Earth Sciences. 1, 11-17.

Babatola, J.O. (2008). A Study of Hospital Waste Generation and Management Practices in Akure, Nigeria African Research Review. 2(3), 292-305

Badmus, G. O.O. S Ogungbemi and O. F. Ola(2014), Hydrogeological Implication of Electrical Resistivity Sounding in Ita-Eku, Ado Ekiti, Nigeria. British Journal of Applied Science and Technology,4(24), 3473-3480

Barker, R.D. (1990),Improving the quality of resistivity sounding data in landfill studies, in Geotechnical and Environmental geophysics, Environmental and geophysics, Environtent Society of Groundwater (ed. S.H. Ward), Society of Exploration 245-251

Cointreau, S.J. (1982), Environmental management of urban solid wastes in developing countries: A project guide, Urban Development Dept, World Bank, Retrieved June 27, 2009 from http://www.worldbank.org/html/fpd/urban //solid -wm/tech paper 5. pdf
Doan, P.L. (1998), Institutionalizing household waste collection: the urban environmental management project in Cote d'Ivoire, Habitat Int., 2 (1), 27 - 39

Fasunwon, O.O., G.B. Jaiyeola, and F.F. Adesugba (2010), Impacts of a dumpsite on the neighborhood of a part of Southwestern, Nigeria, Research Journal of Agriculture and Biological Sciences, 6(3), 204-214.

Ganiyu, S. A., B. S. Badmus, M. A. Oladunjoye, A P. Aizebeokhai, and O. T. Olurin (2015), Delineation of leachate plume migration using electrical resistivity imaging on lapite dumpsite in Ibadan, Southwestern Nigeria, Geosciences, 5(2), 70-80.

Hussain, T., A. Hoda, and R. Khan (1989), Impact of sanity landfill on groundwater quality. Water, Air and Soilpollution, 45, 191- 206.

Ikhifa, I., and M. N. Umego (2016),Mapping groundwater contamination around a dumpsite in Benin city, Nigeria using VLFEM method, Journal of Geography. Environment and Earth Science International, 4(1), 1-9.

Lawal, O. A., A. A. Adegbite, O. Oduyiga, and A. Adeyanju (2013), Determination and Delineation of Groundwater pollution from leachate generated from dumpsite, Ijagun community Odogbolu southwester Nigeria. American Academic \& Scholarly Research Journal, 5(1),35-45

Mor, S., K., Ravindra, R.P. Dahiya, and A. Chandra(2006), Leachate Characterization and assessment of groundwater pollution near municipal solid waste landfill site, Environ. Monit. Assess., 4, 325-334

Ochuko, M.O.(2015), Solid Waste Management in Obantoko Area of Abeokuta, Nigeria, Journal of Emerging Trends in Engineering and Applied Sciences (JETEAS), 5(2), 111115.

Osazuwa, L.B., and N.K. Abdullahi (2008), Geophysics techniques for the study of groundwater pollution. Nigeria Journal Of Physics, 20(1), 163-174.

Slomczynska, B and T Slomczynski (2004) Physicochemical and toxicological characteristics of leachates from MSW landfills, Polish J. Environ. Stud., 13(6), 627-637. 
Wagh, M.P., P.K.Bhandari, and S. Kurhade (2014),

Ground Water Contamination by Leachate,

International Journal of Innovative

Research in Science, Engineering and

Technology, 3(4) :148-152 